\title{
The Income Analysis Of Vegetables Farming With Hydroponic System In Samarinda City, Indonesia
}

\author{
Achmad Zaini \\ Departement of Agribussines, Agriculture Faculty, \\ Mulawarman University, Indonesia \\ Idham Maqshuddi \\ Departement of Agribussines, Agriculture Faculty, \\ Mulawarman University, Indonesia \\ Juraemi \\ Departement of Agribussines, Agriculture Faculty, \\ Mulawarman University, Indonesia
}

\begin{abstract}
The Vegetable farming with hydroponics system is a good prospect. the system is appropriately practiced in urban areas with narrow land. The aim of study to know the income level of vegetables farming with hydroponics system in Samarinda city, Indonesia. The number of respondents taken as many as 13 people with census method. Data were collected by field observation and direct interview with respondent. The result of study show that total costs of vegetables consisting of mustard greens, lettuce and celery was $R p 1,299,232$ respondents $^{-1}$ month $^{-1}$. The total revenue was $R p 4,220,384$ respondents $^{-1}$ month $^{-1}$, so that this business earns the profit was $R p 2,921,151$ respndents $^{-1}$ month $^{-1}$. The value of the income level based on $R / C$ ratio was 3.49. This value indicated that vegetable farming with hydroponics systems is highly profitable
\end{abstract}

Keyword: income, farming, vegetable, hydroponics.

\section{BACKGROUND}

Samarinda city is the capital of East Kalimantan province have the population of approximately 805,688 people and have area of $717.4 \mathrm{~km}^{2}$ (BPS 2016). The large population of Samarinda City is a great potential in marketing food products including vegetables. At the same time it is also a challenge for the stakeholder to be able to provide food needs, while the area of agricultural land in urban areas is getting narrower.

One method of agricultural cultivation including vegetable farming that can be developed for small agricultural land such as urban areas is by hydroponic methods. This method is the development of cultivation technology by controlling the growth of short-lived plants such as vegetables. The combination of hydroponic systems with membranes utilizing of water, nutrients, and pesticides more efficient than soil cultures. The hydroponic system does not recognize seasons and does not require a large area of land compared to soil culture to produce the same unit of productivity (Lonardy, 2006).

According to Indriasti (2013) that product of vegetables by using hydroponics system have better quality than conventional system. However, the hydroponic system requires higher production costs. The production of vegetables with hydroponic system has a high quality that is favored by consumers, especially high-class households. Vegetable products with 
hydroponics systems are often sold in supermarkets, malls, hotels and restaurants. Therefore, Vegetable with hydroponic system has high value. Based on the background, the purpose of this research were to know the amount of production cost used and the level of income from farming of vegetable (mustard, lettuce and celery) with hydroponics system.

\section{RESEARCH METHODS}

This research was conducted for 3 (three) months since March until May 2017 in Samarinda City, East Kalimantan Province, Indonesia. The datas in this research consist of primary data and secondary data. Primary data were obtained by direct observation in the field and interviewed to farmers of vegetable with hydroponics system in Samarinda city. Secondary data are derived from literature relevant to research such as data sources from the Internet, books and previous research related to this research or sources from related institutions.

The number of samples taken as many as 13 people by using the census method. Data is processed by using qualitative and quantitative methods. Qualitative methods are used to describe the description of vegetable farming with hydroponic system in Samarinda city. While Quantitative method is done by calculating the amount of production, price, production factors cost, income, profit and income level of vegetable farming with hydroponics system.

Calculate the total cost with the formula:

Note:

$$
\mathrm{TC}=\mathrm{TFC}+\mathrm{TVC}
$$

$\mathrm{TC}=$ Total Cost

TFC $=$ Total Fixed Cost

TVC $=$ Total Variable Cost

Calculate the average total cost with the formula:

Note :

$$
\mathrm{ATC}=\mathrm{AFC}+\mathrm{AVC}
$$

ATC $=$ Average Total Cost

$\mathrm{AFC}=$ Average Fixed Cost

$\mathrm{AVC}=$ Average Variable Cost

Calculate the total revenue with the formula:

Note :

$$
\mathrm{TR}=\mathrm{Pi} \times \mathrm{Qi}
$$

$\mathrm{TR}=$ Total Revenue

$\mathrm{Pi}=$ Price of Output

$\mathrm{Qi}=$ Output of vegetable farming with hydroponic system

Calculate the profit or net income with the formula:

$$
\operatorname{Profit}(\pi)=\mathrm{TR}-\mathrm{TC}
$$

The income level is calculated by ratio between total reveue and total cost ( $\mathrm{R} / \mathrm{C}$ ratio). The formula is used to find out the impact of the use of production costs can provide benefits. The $\mathrm{R} / \mathrm{C}$ ratio of income and cost ratio can be calculated by the formula:

$$
\mathrm{R} / \mathrm{C} \text { ratio }=\mathrm{TR} / \mathrm{TC}
$$


Indicator:

If the value of $\mathrm{R} / \mathrm{C}>1$ indicates that the farm is profitable

If the value of $\mathrm{R} / \mathrm{C}<1$ indic ates that the farm is lossing

If the value of $\mathrm{R} / \mathrm{C}=1$ indicates that this farming is break even point

\section{Cost of Production Factors}

\section{RESULTS AND DISCUSSION}

The cost of production factors are the total cost incurred during the production process of vegetable farming with the hydroponics system still in progress. Components of production factors cost in vegetable farming with hydroponic system include the cost of equipment depreciation and hydroponics modules, labor costs, nutrients, rockwall, and seeds.

The amount of production cost incurred by 13 respondents for vegetable farming with hydroponics system was Rp. 16,890,024 season-1 with an average of Rp. 1,299,232 season $^{-1}$ respondent ${ }^{-1}$. The value of production cost is influenced by the using of input variables and input operasional. There are difference in the production costs incurred between farmers with each other. This occurs because of the different needs and size of modules used in the production process, the number of vegetables, the selling price of vegetables, and the marketing channels.

\section{Depreciation cost of equipment}

Depreciation value of equipment used for vegetables farming with hydroponics system is the value of depreciation cost of equipment based on technically time of hydroponic module used by farmer for 2-3 years. The equipment used in vegetable farming with hydroponic systemare: Tds ec, pH meter, hydroponic module, netpot, and resun pump. The cost of module depreciation used in vegetable farming with hydroponics systems depends on the extent and price of the module.

The equipment depreciation cost of vegetables farming with hydroponic system for 1 month was Rp 898,415 season ${ }^{-1}$ responden $^{-1}$. The module depreciation cost was Rp. 827,778 season $^{-1}$ responden ${ }^{-1}$ or $91.14 \%$ from depreciation cost total more than other equipment depreciation cost. While, the smallest depreciation cost was the using Tds ec (Rp. 4,952 season $^{-1}$ responden $^{-1}$ or $0.55 \%$ from depreciation cost total.

Table 1. The Depreciation Cost Average of equipment in vegetable farming with hydroponic system per farmer for 1 month.

\begin{tabular}{llrc}
\hline No & Equipments & $\begin{array}{c}\text { Depreciation Cost } \\
\text { per farmer } \\
(\text { Rp/month }\end{array}$ & $\begin{array}{c}\text { Persentase } \\
(\%)\end{array}$ \\
\hline 1. season $\left.^{-1}\right)$ & \\
\hline 2. & Hydroponic Module & 827,778 & 92.14 \\
3. & PH meter & 5,160 & 0.57 \\
4. & Nds ec & 4,952 & 0.55 \\
5. & Retpot & 44,641 & 4.97 \\
\hline & $\quad$ Cost Total & 15,884 & 1.77 \\
\hline
\end{tabular}

Sources : Primary datas, 2017

\section{Variable input costs}

Variable input costs in vegetable farming with hydroponics systems include the cost of seeds, nutrients, rockwall, and labor. The largest variable input cost used for the purchase of plant 
nutrition was Rp. 241,923 season $^{-1}$ respondent $^{-1}$ or $60.36 \%$ of variables input cost total. The high cost is becaused the nutrients is an important source for plants. The dry weather conditions cause rapidly reduced so that the amount of nutrients that are delivered to the plant more volume. The smallest variable input cost is used to purchase seeds of Rp. 18,586 season-1 respondent- 1 or $4.64 \%$ of total variable input cost.

Table 2. The Variable input cost average vegetable farming with hydroponic system per farmer for 1 Season.

\begin{tabular}{llcc}
\hline No & Variable inputs & $\begin{array}{c}\text { Cost of variable } \\
\text { input per farmer } \\
(\mathrm{Rp})\end{array}$ & $\begin{array}{c}\text { Persentase } \\
(\%)\end{array}$ \\
\hline 1. & Seeds & $18 ., 586$ & 4.64 \\
2. & Rock wall & 140,308 & 35.00 \\
3. & Nutrients & 241,923 & 60.36 \\
\hline \multicolumn{2}{c}{ Cost Total } & 400,817 & 100.00 \\
\hline
\end{tabular}

Sources : Primary datas, 2017

The vegetable farming with hydroponics system in Samarinda city does not use much labor in supporting business process. Labors are used at process stages such as seeding, maintenance, cleaning and harvesting. The largest of the labor cost is used at the plant maintenance stage of Rp. 924,715 season $^{-1}$ respondent $^{-1}$ or $65.60 \%$ of total labor cost. The stages of plant maintenance in the vegetable (mustard, lettuce and celery) farming with the hydroponics system requires a activity long time, so the labor costs incurred a lot. The smallest of labor costs are issued at the harvesting stage with an average cost of Rp. 114,831 season $^{-1}$ responden $^{-1}$ or $8.14 \%$ of the labor cost total. This is caused at the time of harvesting does not require a long time and a lot of labor.

Table 3. The average of labor cost of vegetable farming with Hydroponic system for 1 season

\begin{tabular}{llcc}
\hline No & \multicolumn{1}{c}{ Stage of activity } & $\begin{array}{r}\text { Labor per farmer } \\
\left(\mathrm{Rp} / \text { season }^{-1}\right)\end{array}$ & $\begin{array}{c}\text { Persentase } \\
(\%)\end{array}$ \\
\hline 1. & Seeding & 204,923 & 15.53 \\
2. & Maintenance & 924,715 & 65.60 \\
3. & Cleaning & 165,100 & 11.71 \\
4. & Harvesting & 114,831 & 8.14 \\
\hline \multicolumn{4}{c}{ Total biaya } \\
\multicolumn{4}{c}{ Sources : Primary datas, 2017}
\end{tabular}

\section{Revenue}

Revenue is the result of products sales received by farmers of vegetables with hydroponics system before it was reduced by the production costs and marketing costs. Type Vegetables with hydroponic system in the research were mustard, lettuce and celery. Revenue is the result of multiplication between production costs and selling price of the product. The price of mustard was Rp 3,961 per bunch per respondent. The price of lettuce was Rp 33,461 per kg-1 respondent ${ }^{-1}$, and for celery was $\mathrm{Rp} 40,307$ per $\mathrm{kg}^{-1}$ respondent ${ }^{-1}$.

The average revenue of the mustard commodity farming for 1 planting season was $\mathrm{Rp}$ $1,100,769$ respondent $^{-1}$ and the average production of mustard commodity from 13 respondents was 266 bunch per respondent. The average of the revenue total of lettuce farming by hydroponic system was $\mathrm{Rp} 2,384,615$ season $^{-1}$ respondent $^{-1}$ from the average production $70 \mathrm{~kg}^{-1}$ respondent $^{-1}$. While the average of the revenue total of celery farming by hydroponic system was Rp 735,000 season $^{-1}$ respondent $^{-1}$ from the average production $18 \mathrm{~kg}$ - 
1 respondent $^{-1}$. The total revenue of higher hydroponic vegetables is lettuce because it has the higher selling price and farmers planted the lettuce more than the others vegetables.

Table 3. The average revenue of vegetables farming by hydroponic system per farmer for 1 planting season

\begin{tabular}{clcr}
\hline No & \multicolumn{1}{c}{$\begin{array}{c}\text { Kind of } \\
\text { vegetables }\end{array}$} & $\begin{array}{c}\text { The amount sold } \\
\text { (per bunch or } \mathrm{Kg}^{-1} \text { ) }\end{array}$ & $\begin{array}{r}\text { Revenue per farmer } \\
\text { (Rp) }\end{array}$ \\
\hline 1. & Mustard & 266 & $1,100,769$ \\
\hline 2. & Lettuce & 70 & $2,384,615$ \\
\hline 3. & Celery & 18 & 735.000 \\
\hline & & & $4,220,384$ \\
\hline
\end{tabular}

Source: Sumber : Primary data (2017)

The amount of the revenue by the farmers of hydroponic vegetables is influenced by the selling price and the number of vegetables that has been sold by a farmer. The difference of the amount of produced vegetables between these farmers are influenced by the capital owned by farmers, especially the capital for making the hydroponics module. Every farmers sells their own vegetables in a bunch, but there is also a farmer that sell hydroponic vegetables in kilo forms. Out of 13 respondents which were asked about why there is a different selling price between farmers, the reason farmers have a different selling price between them is because there are difference ways between these farmers in packaging their products, so the product selling value is very influential on the production, so even it's on the same amount of revenue, there are possibility that the total of the vegetables produced will be different in total. The revenue of the vegetables with hydroponic system can be seen in Table 4 below.

Table 4. The revenue characteristics according to the vegetables kind in Samarinda city

\begin{tabular}{clccc} 
No & Kind of vegetables & $\begin{array}{c}\text { Total of Revenue } \\
(\mathrm{Rp})\end{array}$ & $\begin{array}{c}\text { The Average of } \\
\text { revenue } \\
(\text { Rp Responden }\end{array}$ & $\begin{array}{c}\text { Percentage } \\
\text { (\%) }\end{array}$ \\
\hline 1. & Mustard & $14,310,000$ & $1,100,769$ & 26.08 \\
2. & Lettuce & $31,000,000$ & $2,384,615$ & 56.50 \\
3. & Celery & $9,555,000$ & 735,000 & 17.42 \\
\hline & Total & & $\mathbf{4 . 2 2 0 . 3 8 4}$ & $\mathbf{1 0 0}$ \\
\hline
\end{tabular}

\section{Source : Primary data (2017)}

The revenue of the farmer of hydroponic vegetables in Samarinda has high revenue. According to the hydroponic vegetables type, Lettuce has the highest revenue with the receipt of $\mathrm{Rp}$ $31,000,000$ season $^{-1}$ with the average of Rp 2,384,615 season ${ }^{-1}$ respondent $^{-1}$ with the highest percentage $56.50 \%$, higher than bok choy and celery.

The net income of hydroponic vegetables farming is obtained from the total of the farming revenue reduced by the total of the production costs. The net income of this hydroponic vegetables farming is influenced by the total of the hydroponic vegetables production that sold, production costs for the hydroponic vegetables farming and the selling price of the hydroponic vegetables. The average total of the hydroponic vegetables farming per farmer for 1 planting season is Rp 2,921,151 season $^{-1}$ respondent $^{-1}$.

The net income is influenced by the production costs incurred by the farmers of hydroponic vegetables. The net income is also influenced by the bug attacks, weather and the level of the capital because if there is a large bug attack, the used of the production cost will also be higher 
and the income will be smaller. The weather is also can effect the net income, if the weather keeps changing, the plants will be damaged and the optimal results could not be achieved. If the result is not optimal, the value of the sales will be smaller, the higher level of capital will affect the income because the large production costs and in the end of the day it will reduce the income. So the difference of the income that obtained by every hydroponic vegetables farmers is affected by the difference of the total of the vegetables harvested. This is because the hydroponic vegetables farming is used as a side job by some people and most of their labors comes from their own family. As a source of income, the hydroponic vegetables farming has the potential to be able to absorb the labor in the local environment so it can reduce the unemployment. The total income of the hydroponic vegetables farmer in Samarinda is $\mathrm{Rp}$ $37,974,975$ season $^{-1}$ with the average Rp 2,921,151 season $^{-1}$ respondent $^{-1}$.

Table 5. The average of the net income total of vegetables farming by hydroponic system per farmer for 1 planting season.

\begin{tabular}{clc}
\hline No & \multicolumn{1}{c}{ Component } & Per farmer $\left(\right.$ Rp season $\left.{ }^{-1}\right)$ \\
\hline 1. & The average of revenue & $4,220,384$ \\
2. & The average of Production & $1,299,232$ \\
& Cost & $2,921,151$ \\
\hline \multicolumn{2}{c}{ Net Income (profit) }
\end{tabular}

\section{Analysis of R/C Ratio}

The R/C Ratio analysis is used to determine the profitable level of the bussines. The R/C Ratio value is obtained by comparing the revenue value and the total of production costs. The

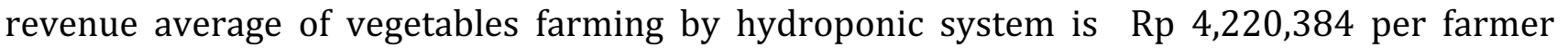
season $^{-1}$ and The production cost average of vegetables farming by hydroponic system is $\mathrm{Rp}$ $1,299,232$ Per farmer season-1. so the value of $\mathrm{R} / \mathrm{C}$ ratio is obtained at 3.49 (this value is greater than 1), thus this vegetables farming with hydroponic system in samarinda city is profitables to develope. The $\mathrm{R} / \mathrm{C}$ ratio value (3.49) showed if the production increase is $\mathrm{Rp}$ 1,000 then the revenue will increase to $\operatorname{Rp} 3,490$.

The selling of vegetables with the hydroponics system not takes a long time in the city of Samarinda. This is because the demand for vegetables with hydroponics systems in Samarinda is quite high, even often farmers are unable to supply the needs of consumers because the vegetable production is still low. This vegetable marketing channel is a zero level because farmers sell it to consumers directly.This shows that vegetable farming with hydroponic systems is profitable and prospective in the future.

\section{CONCLUSION}

Total cost of vegetable farming with hydroponic system by 13 respondents were Rp $16,890,024$ season $^{-1}$, with average $\mathrm{Rp} 1,299,232$ season $^{-1}$ respondent $^{-1}$, while total income of vegetable farming with hydroponic system by 13 respondents were Rp 54,865,000 season ${ }^{-1}$ with average per respondent Rp 4.220 .384 season $^{-1}$ so obtained profit value of Rp 37.974 .975 season $^{-1}$ or an average of Rp 2,921,151 season $^{-1}$ respondent $^{-1}$.

Based on R / C ratio analysis showed that vegetable farming with hydroponics system in Samarinda city, Indoensia was very profitable, let alone farmers able to sell vegetables to consumers directly. 


\section{BIBLIOGRAPHY}

Agustina H. 2009. Efisiensi Penggunaan Air Pada Tiga Teknik Hidroponik Untuk Budidaya Bayam Hijau. Depok: Departemen of Biologi, University of Indonesia.

Anggayuhlin R. 2012. Studi Populasi Tanaman Terhadap Peningkatan Produktivitas dan Konsumsi Air Tanaman Bayam Hidroponik [skripsi]. Bogor : Departemen Agronomi dan Hortikultura, Fakultas Pertanian, Institut Pertanian Bogor.

Anggraini A. 1999. Budidaya Sayuran Hidroponik Dengan Metode NFT Ditinjau Dari Sisi Finansial dan Marjin Pemasaran (Kasus Kebun Studio Agribisnis, Pasir Sarongge Cipanas, Kecamatan Pacet, Kabupaten Cianjur, Propinsi Jawa Barat). Economic Social Departement, Bogor University.

Astuti MD. 2007. Optimalisasi Produksi Sayuran Hidroponik PT Saung Mirwan Di Desa Sukamanah, Kecamatan Mega Mendung, Bogor [skripsi]. Bogor : Magister of Agibussines management program, Bogor University.

Boediono, 2002. Pengantar Ilmu Ekonomi No. 1 Edisi 2 (Ekonomi Mikro). BPFE Yogyakarta

Chow V. 1990. The Commercial Approach in Hydroponics. International

Seminar on Hydroponic Culture of High Value Crops in The Tropics in

Malaysia, November 25-27.

Daniel, M. 2002 Pengantar Ekonomi Pertanian. Bumi Aksara Jakarta

Ginting D. 2009. Analisis Kelayakan Investasi Pengusahaan Paprika dan Timun Jepang Hidroponik Pada PT Horti Jaya Lestari Kabupaten Karo, Provinsi Sumatera Utara[skripsi]. Bogor : Departement of Agribisnis, Management and economic Faculty, Bogor Univesity.

Halim P. 2000. Faktor-Faktor yang Mempengaruhi Keputusan Pembelian Sayuran Hidroponik di PT Hero Supermarket Cabang Pajajaran Bogor. Departement of agriculture ecomonic social. Bogor University. 